\title{
Age and the Factors That Influence Second Language Acquisition
}

\author{
Pei Shuchen
}

China

\begin{abstract}
In the process of learning a second language, a lot of factors play the different roles, such as age, intelligence, environment and so on. This essay firstly introduces the critical period hypothesis and its theoretical background, and then makes a brief review of the research about critical period hypothesis, paying major attention to the age factor. Finally, the factors that influence second language acquisition will be discussed.
\end{abstract}

Keywords: age, critical period hypothesis; second language acquisition; factors

\section{INTRODUCTION}

During the past half century, lots of research concerning critical period hypothesis $(\mathrm{CPH})$ in second language acquisition both here and abroad has continued to catch the interests of researchers. Nevertheless, Thomas Scovel (2000) points out that the study of CPH has engendered even more interest and controversy now than in any previous decade. What has been called as critical period is a typical period during which people can acquire a language easily and rapidly without external intervention and any teach. It is Penfield (1975), a famous neurosurgeon, and Roberts (1959) who firstly introduce this view. They argued that 'language acquisition is most efficient before age nine....when the human brain becomes stiff and rigid'. This idea was accepted by Lenneberg(1967) and moreover he put forward the critical period hypothesis. At first, $\mathrm{CPH}$ was aimed to first language acquisition (L1), but it aroused strong response in the field of second language acquisition (SLA) and be applied to SLA. Later, collecting the data from aphasia and mental retardation patients, Lenneberg(1967) linked the notion that the optimal period of learning a language is before the age of ten. At the very beginning of learning a language, both hemispheres of the brain participate in language acquisition, so language can be acquired effortlessly and naturally before the state of brain puberty. However, with the lateralization of brain and the gradual loss of plasticity of neurological system at the age of ten, most people will find it more and more difficult to acquire a language. That is why Lenneberg(1967) believes that children always have superiority in second language acquisition when compared with adults in the aspect of physiology. We also know that many factors play the important roles, such as age, cognition, affection, motivation and individual differences. So when we do some research about the critical period hypothesis, some questions such as "whether CPH exists or not", "whether people should start to learn a language as soon as possible", "how to divide the periods" "to what extent the age factor influence second language acquisition" are still undefined. In this paper, we will talk about the age factor in second language learning from the perspective of $\mathrm{CPH}$ and after which some other factors concerned to affect second language learning will be given.

\section{Literature REVIEW}

Since the critical period hypothesis was introduced by Lenneberg(1967), a lot of researchers and scholars showed the great interest on $\mathrm{CPH}$ and it soon was applied to second language acquisition. Not all the researchers and scholars approve of this theory .There are both supporters and protesters here and abroad. This part will make a comprehensive survey of some distinct literature. Huang Yiping holds a neutral attitude towards CPH. Huang Yiping has mentioned an interesting phenomenon, as many research do, that indicate many children from the immigrant families can speak a new language indistinguishable from native speakers though their parents cannot speak it (Huang Yiping, 2011). Furthermore, although some adults L2 learners communicate fluently in the target language, various subtle differences as accent, word choice, or grammatical features can distinguish them from those speakers who began to learn the language in their childhood (Lightbown \&Spada, 


\section{Pei Shuchen}

2006).It is proved that children do better than adults in L2 learning .However, there are many differences between children and adults. Age factor is the only one being proved through this phenomenon. Yao Runying has made a statement that actually there is no evidence to clarify that children are superior to adults in second language (Yao Runying, 2015). When learning a second language, children, adolescents and adults respectively have their own features, advantages and disadvantages. As Wang Weiyi has claimed, It is inadvisable to introduce a massive English Education to the primary schools now (Wang Weiyi, 2011). Although the critical period for children to learn a second language is from 2 to puberty, the characteristics of primary school determine the infeasibility of the primary schools English education in China today. Recently in China, the lack of language environment is one of the biggest obstacle for L2 learning .Most people, whatever children, adolescents and adults learn a foreign language for some certain purposes, such as passing tests, getting higher education. The total communicative environment in English has not been created in China and is hard to be built in the future. If more attention has been paid to oral English, the key point people will focus on is to communicate, not to pursue foreign language proficiency to reach the same level as their mother tongue. According to $\mathrm{CPH}$, the qualified English teachers are the priority factor in the process of L2 acquisition, but the truth is that qualified English teachers have been in need for a long time. Once the incorrect accent or pronunciation children learnt or imitated from an unqualified teacher and finally get used to it, It is hard for them to correct because they have learnt it effortlessly and deeply. With all the contradictions and unclear questions, the research of $\mathrm{CPH}$ has a long way to go.

\section{Critical Period Hypothesis}

As has been mentioned above, Lenneberg(1967)firstly introduced CPH and finally be applied to second language acquisition. In the development of the CPH theory, a famous research article written by Johnson and Newport (1989) who conducted a grammatically judgment test and an oral test of Chinese and Korean speakers was highly praised by other scholars. The research objectives are children ,adolescents and adults from 3 to 39 whose mother tongue are Chinese or Korean immigrated to America at different age period and then started to learn English in America. The research shows that children who begin to learn English before 7 can reach the approximate proficiency of native speakers. On the contrary, those who start to learn English after 7 obviously have less native-like language fluency. In addition, Oyama (1978) also investigated 60 Italian who have lived in America for 5 to 18 years since they moved to America at the age of 6 to 20. The investigation found that only those Italian who arrived in America before 12 can speak English as almost the same accent as American. And there is no direct relation between accent proficiency and length of years lived in America. From the above related research, It is firmly demonstrated that age has close relationship with second language acquisition. But the more specific and certain period of $\mathrm{CPH}$ is unclear now, so it is impossible to simply make a conclusion that children should study foreign language as early as possible.

\section{The Influence of Age Factors on Second Language AcQuisition and Reason}

As every language learners know, language acquisition, no matter L1 or L2, is a comprehensive and complex process including listening, speaking, reading, writing and translating. Each part of Language has its own features. In the meantime, different language learners differs in terms of affective factor, age factor, motivation, attitude and purpose. Phonetics, semantics, syntax, vocabulary and so on are involved in the language teaching process. Service and Craik(1993)has conducted a research to authenticate the superiority of children when learning a second language compared with adults. The research finally found the loss of superiority of children in the aspect of vocabulary acquisition. Burstall even puts forward that elder learners can learn a second language more efficiently in grammatical acquisition (Cao Ling, 2012).In spite of the various voices from scholars and researchers, age factor has the great influence on SLA, especially phonetics acquisition.

\subsection{Neurology}

The first presence of $\mathrm{CPH}$ is based on the biology and neurology. Lenneberg discovered language acquisition of children will not be affected when their left brain accidentally get injured. Otherwise, adults will. The evident language barriers will appear when left brain-injured adults learn a language. The neurological explanation is in childhood, left and right brain simultaneously coordinate to control the language learning. Even someone gets injured in left brain, the right brain can take the 
responsibility of coordinating the language acquisition. But the lateralization and the loss of neurological plasticity after puberty lead to the inferior in language acquisition of adults. From this aspect, children do have more advantages than adults to learn a second language.

\subsection{Universal Grammar}

In Chomsky's Philosophy of language, universal grammar is defined as some universal rules or principles of language acquisition. Chomsky believes that the ability of language acquisition is innate and children are born with a language acquisition device (LAD).Children are ready to pick up any language as his first language as long as they are brought into contact with it. Once the children are under the environment of language, LAD will be triggered. The second language acquisition will be achieved fast and effectively. But the LAD will not exist all the human life. The faculty of language will decline with time goes by.

\subsection{Personality Factor}

Personality factors have great impact on the level of language acquisition. Some specific factors will be mentioned here. First one is affective factor. Compared with children, adults are more likely to be afraid of making mistakes, be shy and be over-self-esteem. The most common things children have done is to imitate and to repeat. In order to have the same pronunciation or accent as the one mimicked, children will try their best to correct their oral language and finally reach the native-like proficiency. Contrarily, adults are open to accept the differences existed between themselves and natives, even treat them as a kind of symbol of status.

\section{Dispute ANd COMmentary ON CPH}

$\mathrm{CPH}$ paid most attention on the successful children learners. However, it is hard to use CPH to explain the causes of unsuccessful children learners who start learning second language at a very early age and the successful adults who finally reach the approximate language capacity same as natives. Krashen's Input Hypothesis has mentioned that all the L2 learners, no matter how old the learners are, can acquire the target language as long as there are large input and affective filter. Age is not a predictor to the success of L2 learning. Adults can master a second language well and if the time of children and adults to study and use the second languages is the same, adults may show greater learning effect. Adults may make greater progress with the other factors same as children, especially in grammar and vocabulary. These factors include motivation, attitude, mother tongue and so on. The differences in neurology between children and adults cannot simply point out the essential reasons about the significant difference between L2 learners. Many supporters of CPH hold that children have the superiority in oral language. The younger the learner is, the more standard the pronunciation is. Age is not the main factor affecting the accuracy of pronunciation and intonation. Lots of factors mixed with age have influence on the pronunciation and intonation. There is no direct relation between age and pronunciation. Initially, the $\mathrm{CPH}$ is applied in first language acquisition but in second language acquisition, no one can ignore the interference of mother tongue. Here refers to the pronunciation and sound of mother tongue. It is also be mentioned to certify the existence of CPH that the affective fliter of children is low so children are more inclined to imitate and be bold to speak loudly without being afraid of making mistakes, which is the advantage for children to learn a second language. However, this advantage can also be made by social and psychological factors.

\section{The Other Factors that Will Influence Second Language AcQuisition}

After reviewing some literature about $\mathrm{CPH}$, it is definitely accepted that age plays a significant part in the course of acquiring a second language, but age should not be a primary cause. Different age groups have their own potentials and abilities to learn a language well on the condition that the great and necessary learning prerequisites have been made. Besides age factors, some other factors need to be taken into consideration. In order to find out what factors have influence on second language learning. It is necessary for us to review the first language learning process. First language learning process can reveal the nature and universal characteristics of language learning. When children learn their mother tongue, there are four external factors facilitating language acquisition, which are the real context, intercourse needs, mass contact and communicative interaction. Language learning can be facilitated by changing those four external factors in the process of children's mother tongue learning and adults' second language learning. However, age is the internal factor for language acquisition. No one can change his physiological factors to adapt to the language learning, only in the way of learning a second language according to the characteristics of ages. The internal factors, of course, still include 
intelligence, learning capacity, recognition style, characteristic and emotional factors. In the following parts, some of these factors will be discussed.

\subsection{Four External Factors}

The four external factors refer to real context, intercourse need, mass contact and communicative interaction. Language should be acquired in the process of communication and intercourse with the motivations and purposes. When children learn a language, they learn it by its meanings for the purpose of expressing their own meanings, not by words, sentences, structure and grammar. Nevertheless, the majority of students in China learn English just for answering grammatical questions and passing the exams. That is a direct reason for the fact that so many Chinese second language learners cannot apply it in daily life. Firstly, Real context provides an actual and real environment for second language learner to apply it and become familiar with it. If we ignore the context, the representation of learned English will match Chinese context wrong. In China, most children who are learning English as second language may encounter the problems of language application and differentiation. For example, students are usually confused about the words "ask, demand and require" because in Chinese, all of them are translated to “要求”.But if we put those three words to their own context, it is not hard for us to find that if you ask someone something, you say something to them in the form of a question because you want to know the answer. If you use require, it means that you need it or it is necessary. And demand is ask in a very forceful and firm way. Without context, there is no way to have the real and correct application of language. Secondly, Intercourse needs is the driving force of language acquisition. It is an interesting phenomenon that when Chinese students are required to speak English or communicate with others in English, they can only use the target language for several minutes after which most of the students will choose to speak in Chinese because they find it easier for them to communicate with Chinese students who share the same mother tongue and more convenient to express their meanings and finally reach the goals. So due to the lack of intercourse needs, students lose the most important opportunity for both children and adults. Thirdly, the rules and grammars of a language should not be learned by rote, Based on the mass contact, mass imitation and repetition, grammar and rules can be created automatically, such as the first language acquisition. No one has systematically learnt the grammar but it is not an obstacle for people to use it fluently. What's more, communicative interaction will strengthen the former three factors. Children need these four factors to acquire a language, as well as adults.

\subsection{Mother Tongue}

One of the main reason of the fact that children show their superiority in second language learning is that the interference of mother tongue for children is relatively less than that of adults. If the second language is more similar with mother tongue, it is easier to acquire second language. In Holland, almost everyone can speak English fluently on the condition that their students usually start to have English class at the age of ten, far later than Chinese students. Why do they still learn it so well? It is because that the sentence structure, the culture as well as living experiences of Dutch and English share lots of similarities.

\subsection{Other Factors}

The first factor is intelligence. Some hold that there are some people acquiring language faster than others because they are more intelligent. On the contrary, everyone can use language to express their meanings and thoughts under the condition of abundant context and interaction whether one is intelligent or not. Children are not so intelligent compared with adults, but they still learn language well, even faster than adults. In addition, positive attitude and strong motivation can facilitate second language acquisition greatly.

\section{CONClusion}

Above all, whether $\mathrm{CPH}$ exists or not is still not clear. However, the age is definitely an internal factor affecting language acquisition. The research about $\mathrm{CPH}$ should take into account almost all theories and findings in terms of language acquisition. Age cannot have influence on language acquisition alone. Language is the communicative product of human beings, so the research about factors affecting language acquisition cannot overstate any one factor. The language learning should start and can be acquired by everyone at the most appropriate time in the most appropriate ways with great efforts. 


\section{REFERENCES}

[1] 杨连瑞,崔鹏.(2012)论争中的临界期假说再思考.《外语教学理论与实践》.2012(03):43-49

[2] 曹玲.(2012). 关键期假说与第二语言习得. 《内蒙古农业大学学报（社会科学版）》.2012.(0 4):371-372

[3] 胡萄,罗胜杰.(2016).第二语言习得的关键期及最佳年龄研究.《海外英语》.2016(14): 191192

[4] 刘振前.(2003).第二语言习得关键期假说研究评述《当代语言学》.2003(03):158-172

[5] 林庆英.(2013).二语习得关键期假说之研究现状述评.西安农业大学学报.2013(05):89-91

[6] 张巧娟.(2007).语言写的关键期假说的探讨.厦门教育学院学报.2013.(01)60-62

[7] 黄一平.(2011).A Critical Review of Critical Period Hypothesis in Second Language Acquisition. Overseas English,2011(07):296-298

[8] Li Qin.(2013).Comprehensive Review on "Critical Period Hypothesis" and the Role of Age in Second Language Learning. Overseas English,2013(18):280-282

[9] Yao Runying .(2015).Critical Period Hypothesis and Second Language Acquisition. Overseas English,2015(10):235-236

[10] Wang Weiyi.(2011).On the Critical Period Hypothesis and the Infeasibility of the Primary Schools English Education in China Today. Overseas English,2011(12):155-156

[11] Yan Dan.(2012).The Implication of Critical Period Hypothesis on English Teaching. Lecture Notes in Information Technology.2012(2):33-34

[12] Brown,H.D.(2001).Principles of Language learning and Teaching. Bei Jing: Foreign Language Teaching and Research Press

\section{AUTHOR'S BIOGRAPHY}

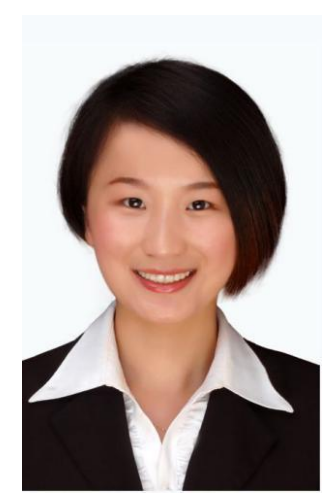

Pei Shuchen, is a postgraduate student at the China West Normal University in the School of Foreign Languages. Her research interests and areas of postgraduate student include Curriculum and Pedagogy, English Teaching and Electronic Information Technology. 